\title{
Palynological study of pre-Siwalik sediments in Sub-Himalaya of central Nepal
}

\author{
Upendra Man Singh Pradhan and Shardesh Raj Sharma \\ Petroleum Exploration Promotion Project, Department of Mines and Geology \\ Lainchaur, Kathmandu, Nepal
}

\begin{abstract}
ABSTr.ACT
The pre-Siwalik sediments are exposed in the inner Terai valley of central Nepal. The sediments occur within the Lower Siwalik and lie to the north of Marin Thrust. Slices of pre-Siwalik sediment might have brought up by thrusts. Since no fossils have been reported from these pre-Siwalik rocks, their age is referred to range from Gondawana to Miocene.

In this paper, an attempt is made to determine the stratigraphic position and age based on the palynological study. A number of spores and pollen are recorded from the samples. However, the palynomorph assemblages in the samples include only stratigraphically long-ranging taxa (Eocene to Quaternary). The identified Compositae type along with Aabiespollenites, Caryapollenities, Psilamonocolpites, Retitricopites etc are found belonging to Miocene or younger. Zoncostites ramonae (mangrove) is assigned to be Late Eocene or younger age where as the Dinocyst Lingulodinium machaerophorum suggests the sample belonging to Tertiary or younger. Besides the pre-Siwalik outcrops are lithologically correlable with the red beds of Murree of India and Pakistan that are assigned as Oligocene-Miocene age. Hence, considering the palynomorph assemblages, its recommended age and paleo-environment including the lithological correlation, the pre-Siwalik sediments of the present area must have deposited in Tertiary time and probably may range from Oligocene to Miocene.
\end{abstract}

\section{INTRODUCTION}

The pre-Siwalik rocks are exposed within the Siwalik rocks of central Nepal. The area is located north of Bakiya Khola valley, in the Bagmati River section and also in the northern parts of Marin Khola valley. The sediments occur within the Lower Siwaliks and to the north of Marin Thrust (Fig. 1).

A few research works have been carried out on the preSiwaliks and basic volcanics that occur in the Bagmati River and Marin Khola area of central Nepal (Adhikary and Rimal 1996). No fossils have been reported so far from this area. Therefore, these sediments are correlated with different formation ranging from Gondawana equivalent to the Lower Siwaliks (Pradhan and Sharma 1999).

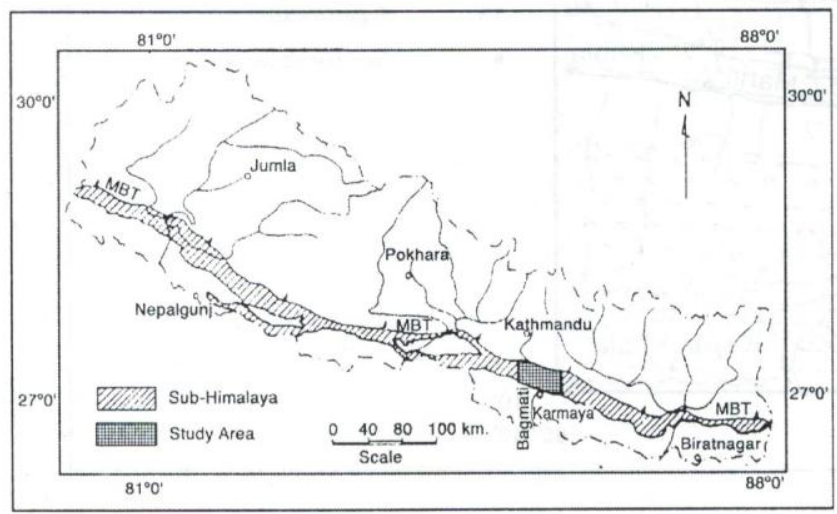

Fig. 1: Location map of the study area
Herail et al. (1986) described the occurrence of "substratum outcrops" in the Dowar Khola, Sindhuli District. They inferred Gondwana age for the rocks in the lower section of the Dowar Khola, while the lowest sedimentary rock sequence consisting mainly of sandstone and the overlying red beds in the upper section were equated to the Dharamshala-Muree beds. They have also reported the occurrence of volcanic rocks in both the lower and upper sections inter-layered with the red sediments. Subedi and Sharma (1991) observed basic intrusives within the Lower Siwaliks which are exposed in some streams, east of Bagmati River. They did not recognise the pre-Siwalik rocks. Kaphle and Einfalt (1992) studied the doleritic volcanic rocks occurring within the Lower Siwaliks (host rock) exposed in Dowar Khola, a tributary of the Marin Khola in central Nepal. They have inferred a very young i.e. post mid-Miocene volcanic activity within the Siwaliks in this area. Gautam et al. (1995) carried out the paleomagnetic study and petrochemistry of the doleritic volcanic rocks and the red beds, exposed in Dowar Khola and Dhanmana Khola of east central Nepal. Considering the best defined remnant direction, they have assigned the age for the deposition of the red beds and the emplacement of volcanic rocks, sometimes between the Eocene and Early Oligocene times.

\section{GEOLGICAL SETTING}

The study area basically comprises the rocks of Siwalik Group and exposed repeatedly due to thrusts. The Main Boundary Thrust separates the Siwaliks from the overlying 
Lesser Himalaya. Pre-Siwalik rocks are exposed to north of Marin Thrust within the Lower Siwalik (Fig. 2). They extend for about $50 \mathrm{~km}$ in a east-west direction.

The sandstones are mainly red coloured and fine grained, occasionally medium grained and rarely gritty. The altered sandstones exhibit red and white bands. Pre-Siwalik sandstones are hard, indurated and more stratified than the Siwalik sandstones. Intraclast shales are present in the medium grained to gritty sandstones. Shales are mostly observed in the middle and upper sections.

The basic rocks are exposed in several places inter bedding with the red beds and show concordant relation with the host rocks (Kaphle and Eeinfalt 1992). These basic rocks are identified as dolerite volcanics and as basalt and also termed as volcanites. Its exposed thickness varies from $3 \mathrm{~m}$ to $60 \mathrm{~m}$ or more. The rocks are fine to medium grained and reddish brown, green and dark grey in colour. The basic intrusives are usually having vesicular structures filled up with carbonate and chlorite. Some volcanic bodies show amygdaloidal structures (Pradhan and Sharma 1999).

The Siwalik and pre-Siwalik rocks show thrust contact. Along the lower boundary, the contact is concealed and the exposed pre-Siwaliks are usually brecciated. In the upper section of the pre-Siwalik, sharp contact can be seen in some streams where the overlying Siwaliks are found in contact with underlying brecciated rocks. These are the clear evidences of tectonic contact between the Siwaliks and preSiwalik rocks.

\section{PALYNOLOGICAL STUDY}

The pre-Siwalik sediments are devoid of fossils. As the fossils are not found, the palynological study could be useful to determine and the age of the pre-Siwalik sediments.

A few samples from the study area were sent to the Palynological Laboratory of Texas, USA through Texana Resources Company, an oil company in Houstort. The results show that most of the pollen and spores reported have common age. The palynofossils having common and relevant age have been listed here along with its age and palaeo-environment Table 1.

\section{INTERPRETATION}

The palynofossils analysed from the samples show wide range of geological age. These palynomorphs show mostly Miocene or younger age but Tertiary or younger age is also

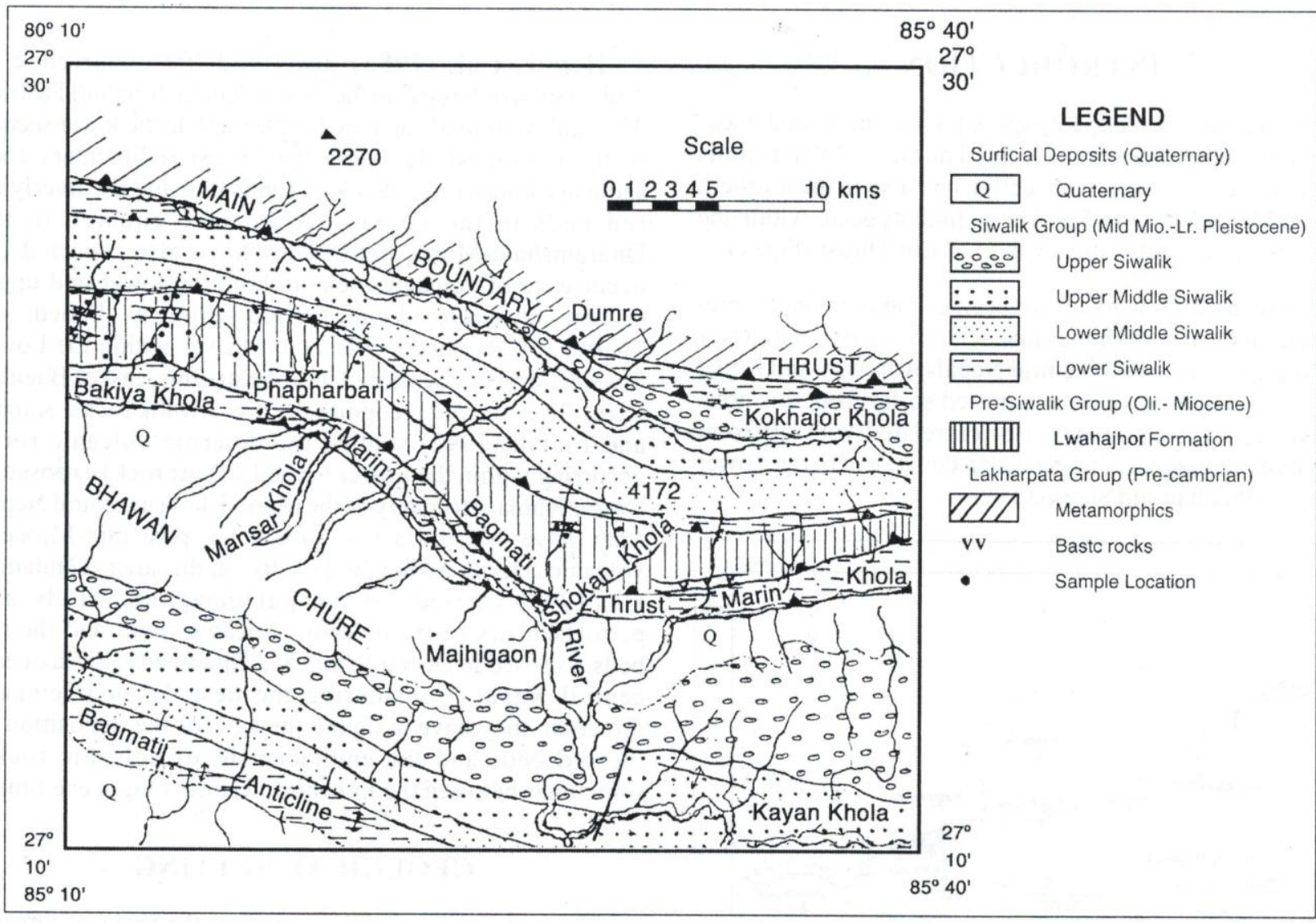

Fig. 2: Geological map of Siwalik and Pre-Siwalik sediments exposed around central part of Southern Nepal 
not uncommon. A few specimens show Cenomanian, Lower Eocene and even younger age. Some palynofossils such as Zoncosites and Compositae etc. are found in both long ranging taxa. Compositae type, are though having long ranging age (Miocene or younger) its earliest stratigraphic occurrences are in sediments of Early Miocene age. But it is also found associated with the other specimen like Abiespollenites spp.,Caryapollenites sp., Inaperturopollenites spp., Psilsmonocopites sp., Pinuspollenites, Retitricopites sp. etc., which are again having wide range of age from Tertiary or younger (Mathur 1984). Presence of Tasmanites in the sample, which has brackish to shallow marine water environment, indicates the transitional zone of the basin, which could be an indication of Oligocene age. Hence, the Tertiary age is found more acceptable to the pre-Siwalik sediments though it is a very broad age. As some palynofossil (Tasmanites) has indication of Oligocene beds and some (Compositae) are specifically identified from Early Miocene, the present sediments could range in age from Oligocene to Miocene.

Evaluating the average occurrences of palynofossils and their relevant paleo-environment, the pre-Siwaliks may have deposited in a non-marine environment and not in marine or paralic to shallow marine environment. The dominance of nonmarine character indicates its deposition in non-marine environment, i.e. younger than marine Eocene rocks. Hence, the pre-Siwalik sediments must be older than Siwaliks.

The pre-Siwalik outcrops are further lithologically correlable with the red beds of Dharamsala- Murree beds of India and Pakistan that are assigned as Oligocene to Miocene age (Herail et.al.1986). Gautam et.al. (1995) have assigned them an age between Eocene to Early Oligocene.

\section{CONCLUSION}

The preliminary palynological study of the pre-Siwaliks has revealed some pollens and spores of stratigraphically long ranging taxa broadly including Tertiary age. The pollens and spores such as Tasmanites and Compositae indicate Oligocene and Miocene age. As the sediments are sliced up between the Siwaliks and some of the sediments show paralic environment also, there is possibility of existence of older marine sediments intermixing with the present pre-Siwaliks. However, the average specimens show deposition in nonmarine to paralic environments.

Considering the present result of palynological study, the paleomagnetic study of rocks of Dowar Khola area and the regional lithological correlation, it may be concluded that the pre-Siwalik sediments of the present study area were deposited in the Tertiary time and the age could be from Oligocene to Miocene.

Table 1: Palynofossils with their age and palaeo-environment

\begin{tabular}{|c|c|c|c|}
\hline SN. & Polymorph assembles & Age & Paleo- environment \\
\hline 1 & Zonocostites ramonae? & Late Eocene or younger & Non-marine to paralic? \\
\hline 2 & Momipites spp.? & Cenomanian or younger & , \\
\hline 3 & Compositae type & Miocene or younger & $"$ \\
\hline 4 & Proxapertites sp.? & Miocene or younger & ” \\
\hline 5 & Betulaceae type? & Miocene or younger & $"$ \\
\hline 6 & Abiespollenites spp. & Miocene or younger & $"$ \\
\hline 7 & Monoporites annulatus & Miocene or younger & $"$ \\
\hline 8 & Psilatricolporites spp. & Tertiary or younger & , \\
\hline 9 & Psilamonocolpites $s p$. & Miocene or younger & , \\
\hline 10 & Retitricolpites $s p$. & Tertiary or younger & Paralic to Shallow marine? \\
\hline 11 & Retitricolporites sp. & Tertiary or younger & , \\
\hline 12 & Inaperturopollenites sp. & Tertiary or younger & , \\
\hline 13 & Taxodiaceaepollenites hiatipites & Miocene or younger & Paralic to Non-marine? \\
\hline 14 & Dictyophyllidites $s p$. & Miocene or younger & , \\
\hline 15 & Piceapollenites spp. & Miocene or younger & , \\
\hline 16 & Pinuspollenites spp. & Miocene or younger & $"$ \\
\hline 17 & Chorate dinocyst & Tertiary or Younger & $\begin{array}{l}\text { Paralic to near shore marine } \\
\text { shallow environment }\end{array}$ \\
\hline 18. & Lingulodinium machaerophorun? & Early Eocene to Quaternary & $\begin{array}{l}\text { Paralic or near shore shallow } \\
\text { marine environment }\end{array}$ \\
\hline 19 & Tasmanites sp.? & Tertiary or younger & Brackish to shallow marine? \\
\hline 20. & Rigidusporonites spp. & Late Eocene or younger & Non-marine to paralic? \\
\hline 21. & Inapertisporites spp. & Miocene or younger &,, \\
\hline 22. & Hypoxylonites sp. & Tertiary or younger & , \\
\hline
\end{tabular}




\section{ACKNOWLEDGEMENTS}

The authors are highly grateful to Dr. R. P. Bshayal, Project Chief, Petroleum Exploration Promotion Project, Department of Mines and Geology, for permitting to publish the paper. The authors are also highly thankful to Mr. Max L. Mazy, President, Texana Resources Company, who helped for releasing the fund for the palynological study.

\section{REFERENCES}

Adhikary, T. P. and Rimal, L. N., 1996, Stratigraphy and structural framework of the Sub-Himalaya, Bagmati River regi,Central Nepal. Jour. Nepal Geol. Soc., v. 13 (Special. Issue), pp. 37-50.

Gautam, P., Upreti, B. N., and Arita, K., 1995, Paleomagnetism and Petrochemistry of the Dowar Khola Volcanics, Central Nepal SubHimalaya. Jour. Nepal Geol. Soc., v, 11 (Special Issue), pp. 179-195.

Herail, G., Mascle, G., and Delcaillau, B., 1986, Les Siwaliks de l'Himalaya du Nepal: un exemple d'evolution geodynamique d'un prisme d'accretion intracontinental. Science de la Terre, Memoire, Nancy, v. 47. pp. 155-182.
Kaphle, K.P. and Eeinfalt, H.C., 1992, Occurrences of volcanoes in the lower Siwaliks formation, an Evidence of Late Tertiary Igneous Activity in the Central Siwalik of Nepal. Jour. Nepal Geol. Soc., v. 8, pp. 11-19.

Mathur, Y. K., 1984,Cenozoic palynofossils, Vegitation, Geology and Climate of the north and northwestern sub-Himalaya Region, India (Off print ). The evolution of the East Asian Environment. Vol. II, Palaeobotany, Palaeoecology and Palaeoanthropology. Editor Robert O. Whyte. Center of Asia Studies. University of Honkong, pp. 505-551.

Pradhan, U. M. S. and Sharma, S. R., 1999, Report on stratigraphy and structrue study of Petroleum Exploration Block -7 (Malangawa), central Nepal. PEPP/DMG, MOI, Kathmandu, Nepal, 33 p.

Subedi, D.N. and Sharma, S. R., 1991, Report on detailed geological sections of Sindhuli and Sarlahi Districts, centralNepal. PEPP/ DMG, MOI, Kathmandu, Nepal, 39 p. 